\title{
Protoplasts of Schizosaccharomyces pombe : An Improved Method for their Preparation and the Study of their Guanine Uptake
}

\author{
By PASCAL HOUSSET AND MARIA NAGY \\ Laboratoire de Génétique, Institut National Agronomique, 75005 Paris, France \\ AND JAIME SCHWENCKE \\ Laboratoire d'Enzymologie, Centre National de la Recherche Scientifique, \\ 91190 Gif s/Yvette, France
}

(Received I9 February 1975; revised 25 April 1975)

\begin{abstract}
SUMMAR Y
A new method is described for the efficient conversion of Schizosaccharomyces pombe cells into protoplasts. The following parameters of guanine uptake determined in whole cells were unchanged in protoplasts: $K_{m}$ value, requirement for an energy source, sensitivity to competitive inhibitors, $\mathrm{pH}$ optimum, as well as the typical variation of the initial velocity of uptake observed during the growth phase.
\end{abstract}

\section{INTRODUCTION}

The complete conversion of Schizosaccharomyces pombe cells into protoplasts has previously been found difficult (Phaff, 1971 ; Mitchison, Creanor \& Sartirana, 1973; Foury \& Goffeau, 1973), and the methods gave a yield of protoplasts varying from one preparation to another. However, during our studies on purine uptake we devised a reliable and rapid method for obtaining good yields of homogenous preparations of $S$. pombe protoplasts.

The method depends on the fact that $S$. pombe cell walls are rich in $\alpha-(\mathrm{I} \rightarrow 3)$ glucan (Bacon et al. 1968; Bush et al. 1974; Fleet \& Phaff, 1973). Some properties of the guanine uptake system of the protoplasts and whole cells are reported here.

\section{METHODS}

Organism and culture conditions. The wild type of strain $972 \mathrm{~h}^{-}$of Schizosaccharomyces pombe was used. It was grown at $30{ }^{\circ} \mathrm{C}$ with vigorous shaking on YPGT medium (Svihla, Schlenk \& Dainko, 196r), containing: $0.5 \%$ (w/v) Difco yeast extract, $0.5 \%(w / v)$ Difco peptone, $3 \%(\mathrm{w} / \mathrm{v})$ glucose, $5 \mathrm{mM} \mathrm{L}$-methionine, $5 \mathrm{mM}$ DL-homocysteine thiolactone and $5 \mathrm{~mm}$ DL-methionine methyl sulphonium chloride. Cells were usually collected during the third or fourth generation after the beginning of the exponential phase.

Protoplast preparation. The yeast $\left(10^{9}\right.$ cells) was washed once with sterile distilled water and resuspended in $10 \mathrm{ml}$ of a solution containing $100 \mathrm{~mm}$-tris, $5 \mathrm{mM}$-EDTA and $5 \mathrm{mM}$ dithiothreitol brought to $\mathrm{pH} 8$ with $\mathrm{HCl}$. After $15 \mathrm{~min}$ at $30^{\circ} \mathrm{C}$, the cells were separated by centrifugation and washed once with sterile distilled water.

The yeast was next incubated $\left(\mathrm{ro}^{9} \mathrm{cells} / \mathrm{ml}\right)$ with gentle shaking at $30{ }^{\circ} \mathrm{C}$ for $80 \mathrm{~min}$ in a mixture of 2 vol. $1 \cdot 2 \mathrm{~m}-\mathrm{KCl}$, I vol. $20 \mathrm{mM}$-dithiothreitol and I vol. snail enzyme (Industrie Biologique Française), to which was added $5 \mathrm{mg} \alpha-(\mathrm{I} \rightarrow 3)$ glucanase $/ \mathrm{ml}$ (3 units per $\mathrm{mg}$ ) and $5 \mathrm{mg} \beta$-(I $\rightarrow 3)$ glucanase $/ \mathrm{ml}$ (Io units $/ \mathrm{mg}$ ). The last two enzyme fractions were kindly 
provided by Dr E. T. Reese (Food Microbiology group, U.S. Army Natick Laboratories, Natick Massachusetts, U.S.A.). Before the yeast was added to the enzyme mixture this was clarified by centrifugation at $12000 \mathrm{~g}$ for $15 \mathrm{~min}$. The protoplasts thus released were centrifuged, washed twice with a solution containing $50 \mathrm{mM}-2-(N$-Morpholino)ethansulphonic acid (MES), $\mathrm{pH} 5,0.6 \mathrm{M}$-mannitol and $0.2 \mathrm{M}-\mathrm{KCl}$, and preserved in a similar medium at $4{ }^{\circ} \mathrm{C}$.

Guanine uptake by protoplasts. The assay of guanine uptake differed from that already described for intact cells (Cummins \& Mitchison, 1967) because of the fragility of the protoplasts. Protoplasts were harvested from the stabilizing medium, and resuspended to a concentration of $2 \times 10^{7}$ protoplasts $/ \mathrm{ml}$ in a solution (MMG medium) containing $50 \mathrm{mM-}$ MES, $50 \mathrm{~mm}-\mathrm{KCl}, 50 \mathrm{mM}$-glucose and $0.6 \mathrm{M}$-mannitol, adjusted to $\mathrm{pH} 5$ with $\mathrm{KOH}$. The suspension was shaken for $10 \mathrm{~min}$ in a water bath at $30^{\circ} \mathrm{C}$. Samples ( $\mathrm{I} \mathrm{ml}$ ) were mixed with an equal volume of $10 \mu \mathrm{M}-\left[{ }^{4} \mathrm{C}\right]$ guanine in $\mathrm{MMG}$ (specific activity $10 \mathrm{mCi} / \mathrm{mmol}$ ) and incubated at $30^{\circ} \mathrm{C}$. At the times indicated, the reaction was stopped by the addition of $2 \mathrm{ml}$ cold $\mathrm{MMG}$ medium containing $40 \mathrm{mM}^{-\mathrm{NaN}_{3}}$ and $0.27 \mathrm{~mm}$-guanine hydrochloride. The protoplast suspension was then centrifuged at $1200 \mathrm{~g}$ for $2 \mathrm{~min}$ and the pellet washed twice with $4 \mathrm{ml}$ MMG medium. After centrifuging, $0.3 \mathrm{ml}$ water and $0.5 \mathrm{ml}$ hyamine hydroxide were added to the protoplast pellet and the mixture was transferred into a scintillation vial with a Pasteur pipette. The test tube was rinsed in three steps with $10 \mathrm{ml}$ of the scintillation solution (5 g PPO and $100 \mathrm{~g}$ naphthalene/l dioxan) which was then also added to the vial. Radioactivity was measured in a Packard Tri-carb scintillation counter, and the counts per minute were converted into moles of guanine taken up by the protoplasts.

Two controls were done in each experiment and assayed for ${ }^{14} \mathrm{C}$ : (i) protoplasts were mixed with $\mathrm{MMG}$ medium containing $5 \mu \mathrm{M}-\left[{ }^{14} \mathrm{C}\right]$ guanine, $40 \mathrm{mM}-\mathrm{NaN}_{3}$ and $0.27 \mathrm{~mm}$ unlabelled guanine, and the suspension was centrifuged immediately; (ii) a sample of the protoplast pellet was added to $300 \mu \mathrm{l}$ sterile distilled water to disrupt the cells and the uptake of guanine was then measured. Both types of control exhibited less than $\mathrm{I} \%$ of the uptake found with intact protoplasts.

Protoplasts were counted in a Malassez counting chamber.

\section{RESULTS AND DISCUSSION}

\section{Protoplast preparation}

The conversion of $S$. pombe cells into protoplasts was complete in $80 \mathrm{~min}$ in the presence of snail enzyme supplemented with both glucanases. When the glucanases were omitted, protoplast yield was only $60 \%$ in $80 \mathrm{~min}$ and did not significantly increase thereafter. The mixture of $\alpha-(\mathrm{I} \rightarrow 3)$ glucanase and $\beta-(\mathrm{I} \rightarrow 3)$ glucanase without the snail enzyme was ineffective. If the cells were not grown in the presence of the sulphur-amino acids mixture of Svihla et al. (196I), the yield of $S$. pombe protoplasts was only $50 \%$ after $3 \mathrm{~h}$. When cells were treated with the snail enzyme supplemented with $\mathrm{I}$ mg of each glucanase $/ \mathrm{ml}$, conversion to protoplasts was slow; 90 to $95 \%$ protoplasts were however obtained in $5 \mathrm{~h}$.

Although some clumping was observed during the first 30 to $50 \mathrm{~min}$, the protoplasts were separate by $80 \mathrm{~min}$.

\section{Guanine uptake by protoplasts as compared with intact cells}

The rate of guanine uptake by protoplasts suspended in MMG medium is shown in Fig. I (a). This rate of uptake was slower than that found for intact cells grown and resuspended in the same culture medium (Fig. $\mathrm{I} b$ ). However, when intact cells were grown in YPGT medium and assayed in MMG medium, the rate of uptake was half that found with the 


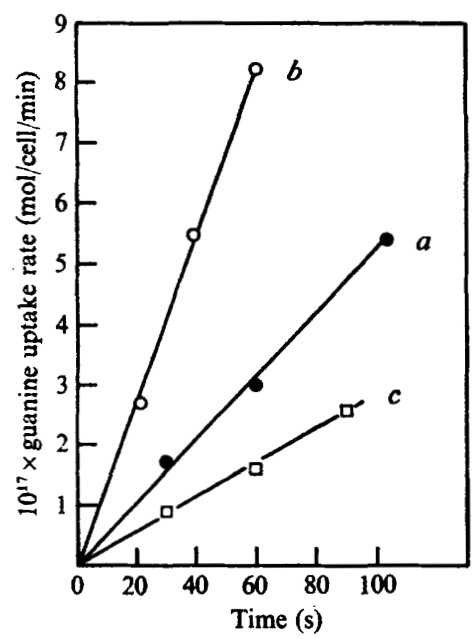

Fig. I

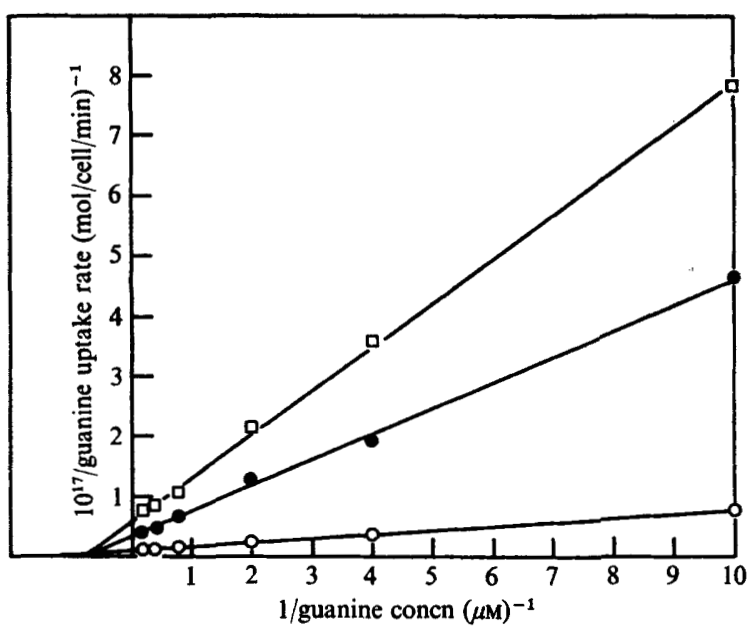

Fig. 2

Fig. I. Initial velocity of guanine uptake by protoplasts in the MMG medium and by intact cells in this and in the glucose-salts medium (Pourquié, 1970). P, Protoplasts were incubated in MMG medium containing $\left[{ }^{14} \mathrm{C}\right]$ guanine and the reaction stopped at the times indicated. $O$, Intact cells harvested from the minimal glucose-salts medium were incubated in a similar fresh medium containing [ ${ }^{14} \mathrm{C}$ ]guanine. $\square$, Intact cells harvested from the YPGT medium were incubated in MMG medium containing $\left[{ }^{14} \mathrm{C}\right]$ guanine.

Fig. 2. Lineweaver-Burk plot of guanine uptake. (, Protoplasts were prepared and assayed as described in Methods except that guanine concentrations were varied as indicated. $K_{m}, I \cdot I \mu_{M}$; $V_{\max }, 3.0 \times 10^{-17} \mathrm{~mol} / \mathrm{cell} / \mathrm{min}$. $O$, Intact cells grown in glucose-salts minimal medium and assayed in a similar solution containing $\left[{ }^{14} \mathrm{C}\right]$ guanine at the concentrations indicated. $K_{m}, 0.7 \mu \mathrm{M} ; V_{\max }$, $11.5 \times 10^{-17} \mathrm{~mol} / \mathrm{cell} / \mathrm{min}$. $\square$, Intact cells grown in YPGT medium and assayed in MMG medium containing $\left.{ }^{14} \mathrm{C}\right]$ guanine at concentrations indicated. $K_{m}, 1 \cdot 1 \mu \mathrm{M} ; V_{\max }, 1 \cdot 5 \times 10^{-17} \mathrm{~mol} / \mathrm{cell} / \mathrm{min}$.

protoplasts (Fig. I c). Furthermore, when whole cells were subjected to the complete treatment for protoplast preparation except that the lytic enzymes were omitted, little uptake occurred in MMG medium. We have as yet no explanation for these effects, but for comparison purposes our control for the uptake of intact cells was measured under the same conditions as for Fig. I $(c)$.

Figure 2 shows how the reciprocal of the guanine uptake rate varied with the reciprocal of the guanine concentration. The reduced rate of guanine uptake by protoplasts and cells measured in MMG medium, as compared with the rate with the cells in minimal medium, was associated with a decrease in $V_{\max }$ rather than a change in $K_{m}$.

Guanine uptake by $S$. pombe cells depends on the energy source, and is reduced in the presence of the competitive inhibitors adenine, hypoxanthine and azaguanine (Pourquié, 1970). The inhibition by natural and synthetic structural analogues was of the same order of magnitude in protoplasts as in the yeasts from which they were derived (Table I). Energy dependence for uptake was also the same for intact cells and protoplasts. The $\mathrm{pH}$ optimum for guanine uptake for both types of cells was between 4.5 and $5^{\circ} 0$.

The initial rate of guanine uptake by $S$. pombe depended on the phase of growth of the culture from which the cells were harvested. The uptake activity reached a maximum three or four generations after the start of the exponential phase and decreased rapidly during the second half of the exponential phase (Fig. 3). This variation in uptake rate was independent of the composition of the growth medium, for yeasts grown in minimum salts-glucose medium, in complete yeast extract medium or in the YPGT medium used in this study gave 
Table I. Effect of energy depletion and of structural analogues on guanine uptake by the protoplasts and cells

Protoplasts and intact cells were grown on YPGT medium and guanine uptake measured in MMG medium as described in Methods.

\begin{tabular}{lcc}
$\begin{array}{c}\text { Alterations in the standard } \\
\text { uptake mixture } \\
\text { (MMG medium) }\end{array}$ & \multicolumn{2}{c}{ Percentage of control } \\
\cline { 2 - 3 } Intact cells & Protoplasts \\
None (control) & I00 & 100 \\
+ Adenine $(4 \mu \mathrm{M})$ & 33 & 40 \\
+ Hypoxanthine $(4 \mu \mathrm{M})$ & 43 & 56 \\
+ Azaguanine $(20 \mu \mathrm{M})$ & 73 & 93 \\
Without glucose & $7 \cdot 4$ & 10 \\
+ Azide (20 mM) & $7 \cdot 4$ & $\mathrm{I} \cdot 7$
\end{tabular}

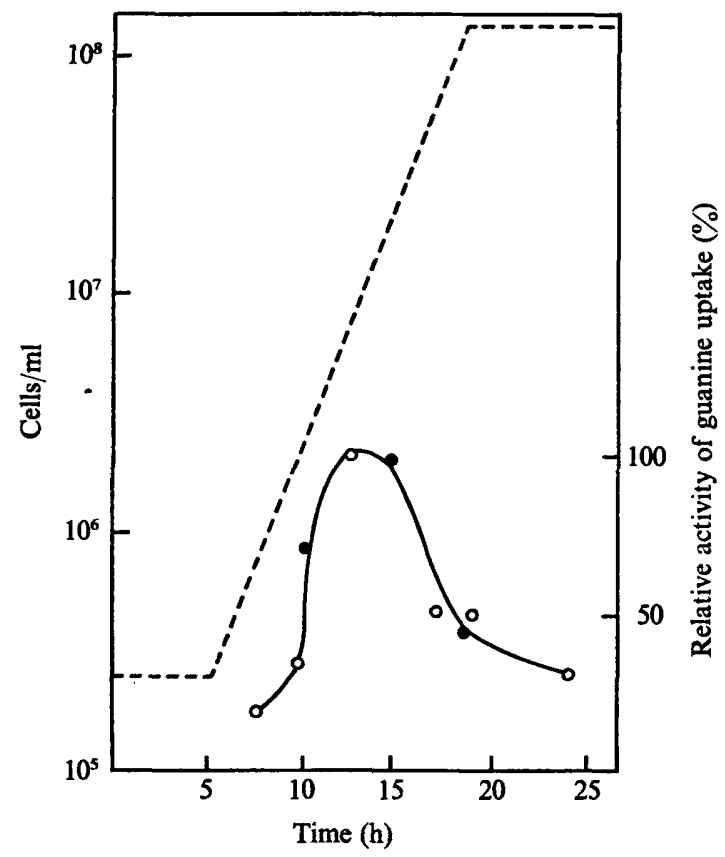

Fig. 3. Effect of the growth phase on the initial rate of guanine uptake by intact cells and protoplasts. Cells grown in YPGT medium (growth curve, broken line) were harvested at the times indicated and their guanine uptake measured in MMG medium either immediately (O), or after their transformation into protoplasts $(\boldsymbol{(})$.

similar results. This dependence of guanine uptake on growth phase remained unchanged after the cells had been transformed into protoplasts (Fig. 3).

In addition to the above characteristics, changes in the initial velocity of guanine uptake shown by whole cells collected at different stages of growth were also shown by the corresponding protoplasts. The relatively slow rate of guanine uptake observed in conditions required for the preservation of protoplasts might be due either to the high osmolarity or the ionic strength of the MMG medium, or to the 'shock' that both cells and protoplasts suffer after transfer from growth medium to the protoplast stabilizing medium. However, transformation of the yeast into protoplasts apparently did not alter the characteristics of the guanine transport system. 
Because the method of protoplast preparation released the entire protoplast, apparently leaving an empty wall, the guanine uptake system is probably not located between the wall and the membrane, where certain transport proteins occur (Heppel, 1971).

This work was supported by the Centre National de la Recherche Scientifique (ERA 224) and the Délégation Générale à la Recherche Scientifique et Technique (74-7-0399). One of us (P.H.) was the recipient of a C.N.R.S. fellowship. We are very grateful to Dr Reese for the supply of $\alpha$ - and $\beta$-glucanases and to Mrs Lambert for her skilled technical assistance.

\section{REFERENCES}

Bacon, J. S. D., Jones, D., Farmer, V. C. \& Webley, D. M. (1968). The occurrence of $\alpha$-( $1 \rightarrow 3)$ glucan in Cryptococcus, Schizosaccharomyces and polyporus species, and its hydrolysis by a streptomyces culture filtrate lysing cell walls of Cryptococcus. Biochimica et biophysica acta 158, 313-315.

Bush, D. A., HorisBerger, M., Horman, I. \& WÜrsCh, P. (1974). The wall structure of Schizosaccharomyces pombe. Journal of General Microbiology 81, 199-206.

Cummins, J. E. \& Mrtchison, J. M. (1967). Adenine uptake and pool formation in the fission yeast Schizosaccharomyces pombe. Biochimica et biophysica acta 136, 108-120.

FleEt, G. H. \& PhAfF, H. J. (1973). Effects of glucanases of yeast and bacterial origin on cell walls of Schizosaccharomyces species in yeast. In Mould and Plant Protoplasts, pp. 33-58. New York: Academic Press.

Foury, F. \& GofFeAU, A. (1973). Combination of 2-deoxyglucose and snail-gut enzyme treatments for preparing sphaeroplasts of Schizosaccharomyces pombe. Journal of General Microbiology 75, 227-229.

HePpel, L. A. (1971). The concept of periplasmic enzymes. In The Structure and Function of Biological Membranes, pp. 224-245. Edited by L. I. Rothfield. New York: Academic Press.

Mitchison, J. M., Creanor, J. \& Sartirana, M. L. (1973). Enzyme synthesis, RNA synthesis and the effects of actinomycin D in protoplasts of the fission yeast Schizosaccharomyces pombe. Proceedings of the Third International Symposium in Yeast Protoplasts, Salamanca, Spain, pp. 229-245. London: Academic Press.

Phaff, H. J. (1971). Structure and biosynthesis of the cell yeast envelope. In The Yeasts, vol. 2, pp. 135-202. Edited by A. H. Rose and J. S. Harrison. New York: Academic Press.

PoURQUIÉ, J. (1970). Antagonism by adenine in the nutrition of Schizosaccharomyces pombe mutants. Inhibition at the level of guanine uptake. Biochimica et biophysica acta 209, 269-277.

Svinla, G., Schlenk, F. \& Dainko, J. L. (I96I). Spheroplasts of the yeast Candida utilis. Journal of Bacteriology 82, 808-814. 